\title{
Spatial Distribution, Genetic Diversity and Food Choice of Box Tree Moth (Cydalima perspectalis) in Croatia
}

\author{
Dinka Matošević ${ }^{1^{*}}$, Ivan Lukić ${ }^{1}$, Audrey Bras ${ }^{2}$, Nikola Lacković ${ }^{1}$, Milan Pernek $^{1}$
}

(1) Croatian Forest Research Institute, Cvjetno naselje 41, HR-10450 Jastrebarsko, Croatia; (2) INRA, UR633 Unité de Recherche de Zoologie Forestière, 2163 Avenue de la Pomme de Pin, CS 40001 ARDON45075 ORLEANS Cedex 2, France

* Correspondence: e-mail: dinkam@sumins.hr
Citation: MATOŠEVIĆ D, LUKIĆ I, BRAS A, LACKOVIĆ N, PERNEK M 2017 Spatial Distribution, Genetic Diversity and Food Choice of Box Tree Moth (Cydalima perspectalis) in Croatia. South-east Eur for 8 (1): 41-46. DOI: https://doi.org/10.15177/ seefor.17-06

Received: 11 Mar 2017; Revised: 18 Apr 2017; Accepted: 19 Apr 2017; Published online: 5 May 2017

\begin{abstract}
Background and Purpose: Box tree moth (Cydalima perspectalis: Lepidoptera, Crambidae) is an invasive species rapidly spreading through Europe and making considerable damage to native and planted European box plants (Buxus sp.). It has up to three generations per year and has no natural enemies in Europe which helps it to spread rapidly and to become highly invasive in its new range. The aim of this paper is to show i) spatial distribution, ii) number of generations; iii) food choice, and iv) genetic distribution of box tree moth in Croatia.

Materials and Methods: Occurrence data of box tree moth were obtained by field observation and data obtained from the general public. The number of generations of box tree moth was studied by direct observation of life stages on plants. Food choice test was conducted on Buxus sempervirens, Ilex aquifolium, Euonymus japonicus and Ligustrum vulgare used as food plants. Haplotype diversity and distribution of box tree moth was done for 5 localities in Croatia and their comparison to the haplotypes from China, Korea and 10 European countries.

Results: Box tree moth has rapidly spread over the whole territory of Croatia in 4 years and it has three generations per year. The larvae showed a clear preference for B. sempervirens leaves and the total consumption was $0.5 \mathrm{~g} / \mathrm{dry}$ weight of box leaves/larva. Three haplotypes were observed and haplotype HT4 was found in 4 out of 5 sampling sites in Croatia. The haplotypes observed in Croatia were present in China, which indicates Chinese origin of Croatian populations.

Conclusions: Suitable European climate, widely available host plants and lack of natural enemies have enabled box tree moth to become highly invasive, to quickly disperse in its new environment and to make devastating damages to ornamental European box plants and hedges.
\end{abstract}

Keywords: invasive species, Buxus sempervirens, haplotypes, total consumption

\section{INTRODUCTION}

Increasing trade between continents has facilitated intentional and unintentional movement of insect species beyond their natural range $[1,2]$. Trade in live ornamental plants is one of the main pathways of the introduction of non-native arthropods to Europe and among them insect pests $[3,4]$. An increasing number of these alien pests originates from Asia [1].

Box tree moth (Cydalima perspectalis Walker, 1859; Lepidoptera, Crambidae) (BTM) is one of the recent introductions of non-native (alien) insect pests to Europe
[5]. It is native to East Asia [6] and in Europe it was first recorded in the Netherlands and Germany in 2007 [5, 7]. It is assumed that it was introduced to Europe with infested European box plants and since then it has rapidly spread to most European countries and the Caucasus region with further trade of infested plants $[6,8]$.

BTM larvae feed on Buxus sp. and cause complete defoliation and plant death [6]. The damage it causes is substantial since European box is widely used as popular ornamental plant in public and private gardens, historical 
parks, cemeteries and other horticulturally important plantings [6]. Very valuable are unique natural European box populations in Europe and in the Caucasus [9] which are threatened by damages of this highly invasive species [10].

BTM overwinters in larval stage between European box leaves spun together with silk. Larvae need an obligate diapause of 6-8 weeks [11] and they complete their development in late spring after feeding voraciously and totally defoliating European box plants. Pupae are concealed in a cocoon of white webbing among the leaves and twigs. The females lay eggs on the underside of leaves in flat, barely visible egg clusters. Larval development takes 17 to 87 days, depending on the temperature [12]. In central Europe BTM develops two generations per year [11, 13], while three generations per year are reported from southern Germany [7], northern Italy [14], southwest Hungary [15], in comparison to three to five generations found in native China $[11,16]$.

BTM feeds only on the leaves of Buxus sp. [13], but Euonymus japonicus Thunb. and Ilex purpurea Hassk are mentioned as host plants in Japanese literature [7, 11]. Invasive species can alter their diet by adjusting to new hosts in the introduced region [13, 17], so there is a concern that BTM larvae could feed on European native species (Ilex aquifolium L., Euonymus latifolius L., E. europaeus L., $E$. verrucosus Scop.) that are growing in various continental and sub-Mediterranean forest communities in Croatia where they form important and biologically diverse understorey layer [18].

Only partial data on the occurrence of BTM in Croatia have been published [19] and since then there have been reports of damages from all over Croatia.

A preliminary genetic study on BTM was carried out by Bras et al. [20] to describe the genetic diversity in the native area (Asia) and in some European countries in the introduction area and to disentangle the invasion pathways of BTM introduction into Europe. They analysed a fragment of the mitochondrial genes COI-COII. For the present study, we used a subset of those data with a focus on Croatia, in order to compare the genetic variation in this country with other European countries and Asia.

Although widely present in Croatia, our knowledge about certain aspects of the biology and ecology of BTM has been limited. Therefore, in our research we focused on the following: i) detailed spatial distribution; ii) number of generations; iii) food choice, and iv) genetic distribution of BTM in Croatia.

\section{MATERIALS AND METHODS}

\section{Spatial Distribution of Box Tree Moth}

Data about the occurrence of BTM in Croatia were obtained by field observation conducted by the authors of this study and by the data obtained from professional nursery growers, other professionals working with plants and the general public (enquiries via the web portal Štetnici $\mathrm{Hr}$ and personal enquiries via phone and e-mail) in the years 2013, 2014, 2015 and 2016. For each location where BTM larvae and damages were found and reported, the name of the location, geographic coordinates and the year of the first damages were recorded. Whenever possible, photographic material was requested from the general public to minimise false identification.

Spatial distribution map of BTM occurrence was made using ArcMap 10.1 (ESRI, USA).

\section{The Number of Generations of Box Tree Moth}

We researched the biology of BTM in 2014 by direct observations of life stages on European box plants. The plants were located in Zagreb (45 $\left.49^{\prime} 12.18^{\prime \prime} \mathrm{N} ; 1^{\circ} 59^{\prime} 22.97^{\prime \prime} \mathrm{E}\right)$ and Jastrebarsko $\left(45^{\circ} 40^{\prime} 14.87^{\prime \prime} \mathrm{N}\right.$; $\left.15^{\circ} 38^{\prime} 41.58^{\prime \prime} \mathrm{E}\right)$. The plants were checked every week from April until October. We did not measure the dimensions of larvae in different larval stages, but only observed the presence of larvae, pupae and adults. Adults were observed on plants, street and home lights on the locations of observations.

\section{Food Choice Test of Box Tree Moth}

Food choice test was conducted in the entomological laboratory of Croatian Forest Research Institute. BTM larvae were collected in April 2015 in Jastrebarsko (45 40'14.81"N, $\left.15^{\circ} 38^{\prime} 47.91^{\prime \prime} \mathrm{E}\right)$. We collected the young overwintering larvae and we tried to choose larvae which were approximately the same size but without determination of exact larval stages. Buxus sempervirens, Ilex aquifolium, Euonymus japonicus and Ligustrum vulgare L. were chosen as food plants. Ilex aquifolium was chosen because it grows naturally in forests and is protected by Croatian law on nature protection. Euonymus japonicus belongs to the same genus as the native E. latifolius, E. europaeus, E. verrucosus. Euonymus japonicus was easily available for the test and is an ornamental plant very often grown together with European box. Euonymus latifolius, E. europaeus and E. verrucosus were not tested since their leaves were not easy to obtain at the time of the test. We assumed that preliminary test on any member of the genus Euonymus could show preference of BTM for this plant genus. Ligustrum vulgare was tested because we received lots of reports from the general public about damages from BTM larvae on L. vulgare and because both Buxus and Ligustrum are often planted in the same hedge.

We used 50 larvae for each food plant, each larva kept separately in a petri dish. They were kept under laboratory conditions of $20 \pm 1{ }^{\circ} \mathrm{C}$ with a relative humidity of $65 \%$ and a photoperiod of 16h:8h (L:D). Fresh leaves were collected every week from the same plant and kept on twigs in glass jars with water. Leaves of chosen food plants were weighed in a fresh state on a Sartorius BD ED 100 (ATL 224-I) analytical laboratory balance (limit $0.001 \mathrm{~g}$ ) and then given to larvae. Fresh leaves were added when the larvae consumed them or when they dried out, usually every day or every other day. All leftover leaf material was collected, oven dried at $70^{\circ} \mathrm{C}$ for 24 hours and weighed.

Total consumption $\left(T_{c}\right)$ was calculated according to Waldbauer [21] using formula: $T_{c}=\left[\left(\mathrm{L}_{w g}{ }^{*}\left(\mathrm{~F}_{w} / \mathrm{D}_{w}\right)\right)-\mathrm{L}_{\mathrm{wf}}\right]$ where $L_{w g}$ is the weight of fresh leaves given to larvae and $L_{w f}$ is leftover leaf material, both of them in dry weight/gram (dw/g). To obtain the value of $L_{w g}$ in dry weight/gram, a coefficient $F_{w} / D_{w}$ ( $F_{w}$-fresh weight of leaves, $D_{w}$-dry weight of leaves) obtained from 10 leaves (similar in shape and size 
to the leaves that were given to larvae) was used. To obtain the dry weight of $\mathrm{L}_{\mathrm{wg}}$ and $\mathrm{L}_{\mathrm{wf}}$, they were oven dried at $70^{\circ} \mathrm{C}$ for 24 hours.

\section{Genetic Distribution}

Sampling of material, DNA extractions, PCR amplifications of COI-COII and sequencing were performed following the protocol described in Bras et al. [20]. Specimens of BTM were collected in the native area (China and Korea) and in the introduced area (Austria, Belgium, Bulgaria, France, Germany, Hungary, Italy, Serbia, Slovenia and Switzerland) as described in Bras et al. [20]. In addition, a total of 18 BTM specimens belonging to 5 localities in Croatia were collected in 2014. Butterflies were collected in Osor and Artatore (Mali Lošinj) and caterpillars were collected on European box plants on three others localities (Zagreb, Vinica, Višnjevac). Haplotype diversity and haplotype distribution were calculated with DNAsp v.5. [22].

\section{RESULTS AND DISCUSSION}

\section{Spatial Distribution of Box Tree Moth in Croatia}

Data on the occurrence of BTM in Croatia yielded a distribution map (Figure 1) with different layers for each year (2013, 2014, 2015 and 2016). In this graphic depiction it is clearly visible that BTM has in 4 years spread rapidly over whole Croatia. The pest was first recorded in Istria in 2012 [23] and the first outbreak was recorded in the region around Varaždin in 2013 [19] (Figure 1). The pest quickly spread eastwards and southwards in 2014, and by the end of 2016 all the locations we examined showed presence of the moth. The spread was facilitated by the movement of infested plant material since European box plants with presence of larvae were observed in several garden centres in Croatia (Dinka Matošević, personal observation). During our research we have seen and received numerous reports on damages on valuable European box ornamental hedges and plantings in Croatia (e.g. Trsteno Arboretum and Lokrum Island near Dubrovnik). European box is also a part of traditional folk costume in the region of Novi Vinodolski, while old European box plants are an important part of public and private gardens in this region. In 2014 and 2015 all European box in this region has been defoliated by BTM which caused loss of valuable old plants and concern among local citizens.

The Number of Generations of Box Tree Moth in Croatia

On the basis of field observations we can assume that BTM has three generations per year in Croatia (Table 1). In 2014, we observed overwintering larvae feeding until the end of May and the beginning of June, pupae and then adults emerging during June. Young larvae were observed from 5 July 2014 and moths were observed flying from 1 to 15 August. Young larvae were again found on leaves from 15 August and adults were observed again in October 2014.

CLIMEX model [11] shows 3 generations per year for continental Croatia (Marc Kenis pers. comm.); 3 generations have been observed in northern Italy [14] and southwestern Hungary [24], which is comparable to our results. The average monthly air temperature in continental Croatia was in June 2014 in the category very warm with average daily temperatures above $25^{\circ} \mathrm{C}$, in August and September 2014 in the category normal and in October 2014 in the category

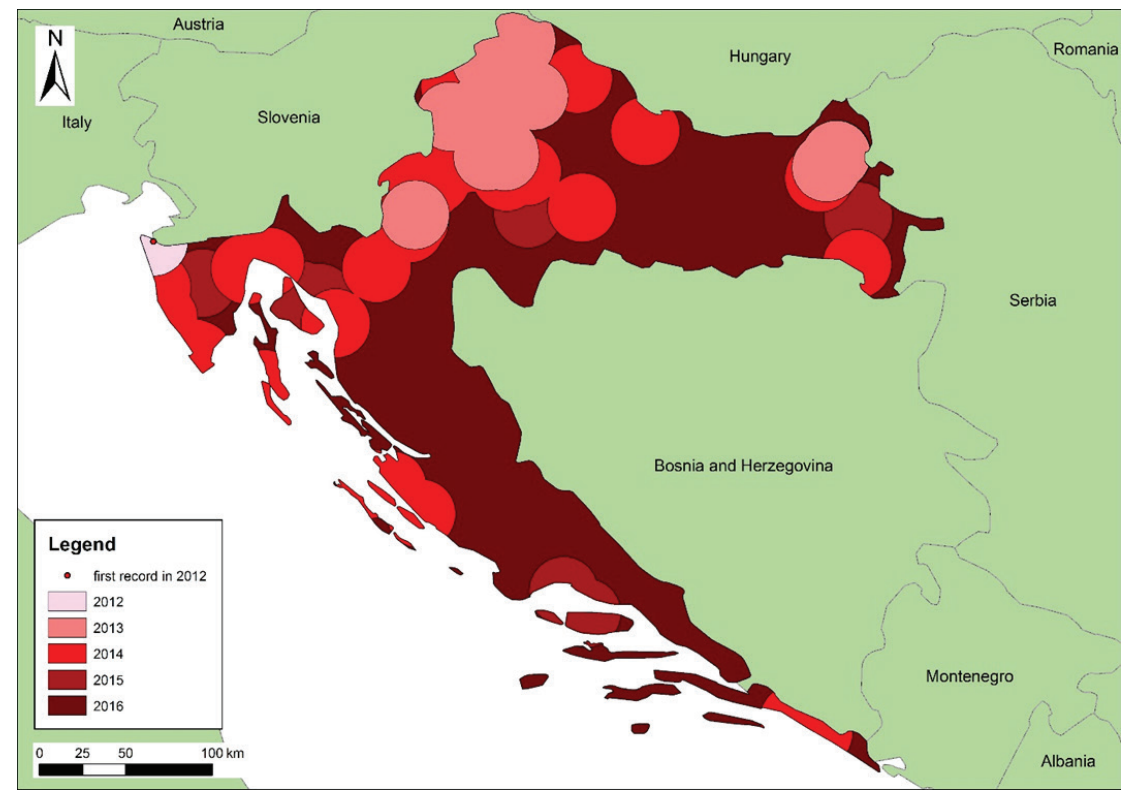

FIGURE 1. The map of yearly spread of box tree moth (Cydalima perspectalis) infestations in Croatia. Infestations are visualized with $20 \mathrm{~km}$ buffers around confirmed infestation points and coloured according to the year of observation. 
very warm [25]. These conditions were favourable for BTM to develop 3 generations per year since larval development takes 23 days at $25^{\circ} \mathrm{C}$, and 17 days at $30^{\circ} \mathrm{C}$ [12] with adults living up to two weeks [6] (Mark Kenis pers. comm.). Very similar occurrence of adults and three generations were recorded in Győr-Bácsa (NW Hungary) in 2014 [24].

\section{Food Choice of Box Tree Moth}

BTM larvae showed a clear preference for $B$. sempervirens leaves. The mortality rate of larvae feeding on European box leaves was $5 \%$ and the total consumption was $0.5 \mathrm{~g} / \mathrm{dry}$ weight of box leaves/larva. Larvae successfully pupated and moths emerged.

Larvae did not develop on the other three tested species (E. japonicus, I. aquifolium and L. vulgare). The mortality rate of larvae on these three species was $100 \%$ with no feeding or growth recorded.

Our results show that BTM do not feed on Ilex aquifolium and Euonymus japonicus and therefore we assume that they pose no threat to native and protected $I$. aquifolium growing in Croatian forests. Although we did not make food test on Euonymus latifolius, E. europaeusand $E$. verrucosus we can also assume that box tree moth is also not able to feed on our native Euonymus species.

\section{Genetic Distribution}

In the native area, 6 haplotypes were observed in China [20]. Among them, 4 haplotypes were present in the introduced area but were not homogeneously distributed between countries (Figure $2 \mathrm{~b}$ ).

In Croatia, a total of 3 haplotypes were observed (Table 2). The haplotype HT4 was the most abundant. It was found in 4 sampling localities including Višnjevac where it was the only haplotype observed in the 5 sequenced specimens $(\mathrm{H}=$ 0) (Figure 2a). We observed one haplotype in Vinica (HT2), which is the first place where a BTM outbreak was observed in Croatia [19].

The haplotypes observed in Croatia were present in China, which indicates Chinese origin of Croatian populations, and which corresponds to the assumptions of Nacambo et al. [11] for the origin of the invasive populations of BTM in Europe. Moreover, Bras et al. [20] observed a spatial genetic structuration in the introduced area with the presence of two groups: West Europe (HT1 mostly observed) and Southeast Europe (HT4 mostly observed). Our results (HT4: 13 specimens for 18 sequenced) indicate that Croatia belongs to the south-eastern group. In addition, high genetic diversity (3 out of the 4 haplotypes present in Europe) observed in Croatia may suggest a multiple introduction

TABLE 1. Field observations of the development of box tree moth (Cydalima perspectalis) in 2014. The presence of larvae on plants is shown in table as circles, and the presence of adults is shown as a butterfly symbol.

\begin{tabular}{|c|c|c|c|c|c|c|c|c|c|c|c|c|}
\hline Month & 1 & 2 & 3 & 4 & 5 & 6 & 7 & 8 & 9 & 10 & 11 & 12 \\
\hline Larvae & o & o & o & o & 0 & $\circ$ & o & 0 & o & 0 & o & $\circ$ \\
\hline Adult & & & & & & & & & & & & \\
\hline
\end{tabular}

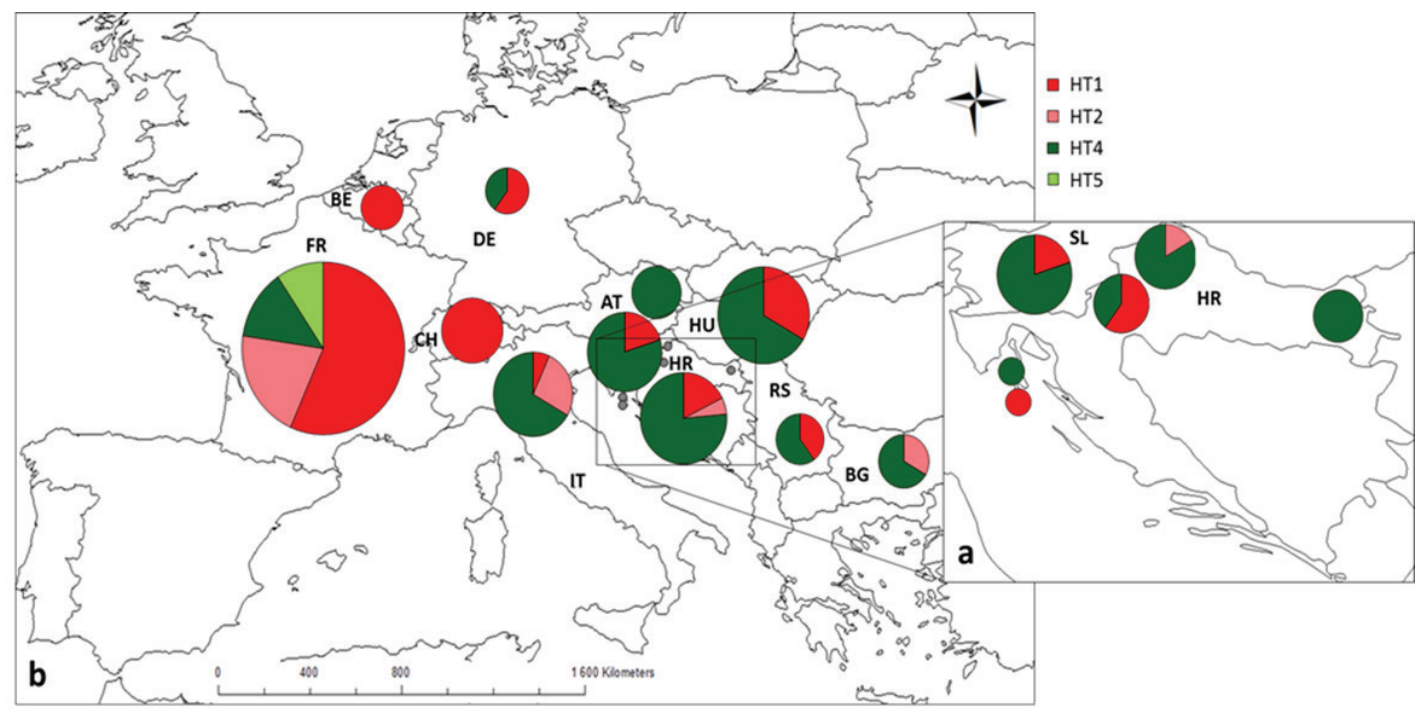

FIGURE 2. Haplotype distribution of box tree moth (Cydalima perspectalis) in Europe based on data (a) from the present study on Croatia and (b) Bras et al. [20] for other European countries. Circle size is proportional to the number of individuals. FR: France; DE: Germany; BE: Belgium; CH: Switzerland; IT: Italy; AT: Austria; SL: Slovenia; HR: Croatia; HU: Hungary; RS: Serbia; BG: Bulgaria. 
TABLE 2. The list of samples of $\mathrm{C}$. perspectalis from Croatia and haplotype distribution per population $(\mathrm{N}=\mathrm{Number}$ of individuals per population, $\mathrm{H}=$ Haplotype diversity).

\begin{tabular}{lccc}
\multicolumn{1}{c}{ Populations } & N & Haplotypes & H \\
\hline Zagreb & 5 & $H T 1(3) ; H T 4(2)$ & $0.60( \pm 0.18)$ \\
Vinica & 6 & $H T 4(5) ; H T 2(1)$ & $0.33( \pm 0.22)$ \\
Višnjevac & 5 & $H T 4(5)$ & 0 \\
Osor & 1 & HT4 (1) & - \\
Artatore (Mali Lošinj) & 1 & HT1 (1) & - \\
Total & 18 & HT1 (4); HT2 (1); HT4 (13) & $0.45( \pm 0.12)$
\end{tabular}

event of BTM. Nevertheless, information on the ornamental plant trade in Croatia will help to better understand invasive pathways of BTM.

\section{CONCLUSIONS}

BTM is an invasive insect pest that has rapidly spread on the whole territory of Croatia in the period of 4 years causing complete defoliation and death of ornamental European box plants. This rapid dispersal and severe damages are possible by developing three generations per year. BTM shows clear preference for Buxus sempervirens only. Croatian haplotypes show a Chinese origin of the species with high probability of multiple introductions by infested plant material. When alien phytophagous insects arrive at a new location, their survival, establishment and spread depend on various factors such as the availability of preferred host plants and the suitability of the local climate [26]. Suitable European climate, widely available host plants and lack of natural enemies [27] have enabled this insect pest to become highly invasive and quickly disperse in its new environment.

\section{Acknowledgments}

We would like to thank Nikola Zorić and Blaženka Ercegovac for their help in field and laboratory work. We would also like to thank Marie-Anne Auger-Rozenberg for her useful comments on genetic distribution. This research has been fully supported by the Croatian Science Foundation (project "Defoliators as Invasive Forest Pests in Changing Climate Conditions" DIFPEST 7616). We would like to acknowledge support for the genetic research from the French Region Centre Val-de-Loire (project INCA APR IR 2015 - 0009 673).

\section{REFERENCES}

1. ROQUES A 2010 Alien forest insects in a warmer world and a globalised economy: impacts of changes in trade, tourism and climate on forest biosecurity. New Zeal J For Sci 40 (suppl.): 77-94

2. LIEBHOLD AM, BROCKERHOFF EG, GARRETT LJ, PARKE JL, BRITTON KO 2012 Live plant imports: the major pathway for forest insects and pathogen invasions of the US. Front Ecol Environ 10 (3): 135-143. DOI: https://doi.org/10.1890/110198

3. KENIS M, RABITSCH W, AUGER-ROZENBERG MA, ROQUES A 2007 How can alien species inventories and interception data help us prevent insect invasions? Bull Entomol Res 97 (5): 489502. DOI: https://doi.org/10.1017/S0007485307005184

4. ROQUES A, RABITSCH W, RASPLUS JY, LOPEZ-VAAMONDE C, NENTWIG W, KENIS M 2009 Alien Terrestrial Invertebrates of Europe. In: Drake JA (ed) Handbook of Alien Species in Europe. Springer, Netherlands, pp 63-79. DOI: https://doi. org/10.1007/978-1-4020-8280-1 5

5. KRÜGER EO 2008 Glyphodes perspectalis (Walker, 1859) - new for the European fauna (Lepidoptera: Crambidae). Entomologische Zeitschrift mit Insekten-Börse 118 (2): 81-83

6. CABI 2017 Cydalima perspectalis (Box Tree Moth). URL: http:// www.cabi.org/isc/datasheet/118433 (2 February 2017)
7. VAN DER STRATEN MJ, MUUS TST 2010 The box tree pyralid, Glyphodes perspectalis (Lepidoptera: Crambidae), an invasive alien moth ruining box trees. In: Bruin J (ed) Proceedings of the Netherlands Entomological Society, 18 December 2009, Volume 21, 107-111

8. GNINENKO YI, SHIRYAEVA NV, SHUROV VI 2014 The box tree moth-a new invasive pest in the Caucasian forests. Plant Health - Research and Practice 1 (7): 32-39

9. DOMENICO FDI, LUCCHESE F, MAGRI D 2012 Buxus in Europe: late quaternary dynamics and modern vulnerability. Perspect Plant Ecol 14 (5): 354-362. DOI: https://doi.org/10.1016/i. ppees.2012.07.001

10. KENIS M, NACAMBO S, LEUTHARDT FLG, DOMENICO FDI, HAYE T 2013 The box tree moth, Cydalima perspectalis, in Europe: horticultural pest or environmental disaster? Aliens 33: 38-41.

11. NACAMBO S, LEUTHARDT FLG, WAN H, LI H, HAYE T, BAUR B, WEISS RM, KENIS M 2014 Development characteristics of the box-tree moth Cydalima perspectalis and its potential distribution in Europe. J Appl Entomol 138 (1-2): 14-26. DOI: https://doi.org/10.1111/jen.12078 
12. MARUYAMA T, SHINKAJI N 1991 The life-cycle of the boxtree pyralid, Glyphodes perspectalis (Walker) (Lepidoptera: Pyralidae). II. Developmental characteristics of larvae. Jpn J Appl Entomol Z 35 (3): 221-230. DOI: https://doi.org/10.1303/ jjaez.35.221

13. LEUTHARDT FLG, BAUR B 2013 Oviposition preference and larval development of the invasive moth Cydalima perspectalis on five European box-tree varieties. J Appl Entomol 137 (6): 437-444. DOI: https://doi.org/10.1111/jen.12013

14. SANTI F, RADEGHIERI P, SIGURTÀ GI, MAINI S 2015 Sex pheromone traps for detection of the invasive box tree moth in Italy. B Insectology 68 (1): 158-160

15. TÜSKE É, MARCZALI Z 2016 Study on the seasonal flight of the box tree moth (Cydalima perspectalis Walker 1859) in county Zala, Hungary in 2015. NÖVÉNYVÉDELEM 77 (52) 2: 65-68

16. TANG SJ, QIN HZ, SUN W 1990 Studies on bionomics of Diaphania perspectalis. Journal of Shanghai Agricultural College 8 (4): 307-312

17. LOCKWOOD JL, HOOPES MF, MARCHETTI MP 2007 Invasion ecology. Blackwell Publishing, Oxford, United Kingdom, $304 \mathrm{p}$

18. VUKELIĆ J 2012 Šumska vegetacija Hrvatske. Faculty of Forestry University of Zagreb, Zagreb, Croatia, $403 p$

19. MATOŠEVIĆ D 2013 Box Tree Moth (Cydalima perspectalis, Lepidoptera; Crambidae), New Invasive Insect Pest in Croatia. South-east Eur forestry 4 (2): 1-6. DOI: https://doi.org/ 10.15177/seefor.13-09
20. BRAS A, COURTIN C, KENIS M, BERNARD A, ROQUES A, ROUSSELET J, AUGER-ROZENBERG MA 2016 L'invasion fulgurante de la pyrale du buis en France et en Europe: diversité génétique et approche phylogéographique. In: Actes de la 4ème Conférence AFPP sur l'entretien des Jardins, Espaces Végétalisés et Infrastructures, Toulouse, France 19-20 October 2016.

21. WALDBAUER G 1968 The consumption and utilization of food by insects. Advan Insect Physiol 5: 229-288

22. LIBRADO P, ROZAS J 2009 DnaSP v5: a software for comprehensive analysis of DNA polymorphism data. Bioinformatics 25 (11): 1451-1452. DOI: https://doi. org./10.1093/bioinformatics/btp187

23. KOREN T, ČRNE M 2012 The first record of the box tree moth, Cydalima perspectalis (Walker, 1859) (Lepidoptera, Crambidae) in Croatia. Nat Croat 21 (2): 507-510

24. HAVASRÉTI B 2017 Kártevő-helyzet a Győr-bácsai fénycsapda alapján - 2007-2011. URL: http://szigetkoz.eu/kartevo.html (2 April 2017)

25. DHMZ 2017 Mjesečno, sezonsko i godišnje praćenje klime. URL: http://klima.hr/ocjene arhiva.php (2 April 2017)

26. ELTON CS 1958 The Ecology of Invasions by Animals and Plants. Springer, New York, United States, 181 p. DOI: https:// doi.org/10.1007/978-1-4899-7214-9

27. WAN H, HAYE T, KENIS M, NACAMBO S, XU H, ZHANG F, LI H 2014 Biology and natural enemies of Cydalima perspectalis in Asia: Is there biological control potential in Europe? J Appl Entomol 138 (10): 715-722. DOI: https://doi.org/10.1111/ jen.12132 